\title{
Identification key to Central European species of Trachytes (Acari: Uropodina) with redescriptions, ecology and distribution of Slovak species
}

\author{
PETER MǍ̌́́N \\ Institute of Zoology, Slovak Academy of Sciences, Dúbravská cesta 9, 84506 Bratislava, Slovakia; e-mail: uzaepema@savba.sk
}

Key words. Acari, Uropodina, Trachytes, identification, redescription, ecological requirements, distribution, zoogeography

\begin{abstract}
A total of 23 uropodine species of the genus Trachytes (Acari, Mesostigmata) are reliably recorded to occur in Central Europe and included in identification keys for adults ( $23 \mathrm{spp}$.) and deutonymphal stages ( $9 \mathrm{spp}$.), respectively. For the first time, the diagnostic characters of deutonymphs of the species T. baloghi, T. minima, T. minimasimilis, T. mystacinus and T. splendida are figured. Ten species found in Slovakia are redescribed (T. aegrota, T. baloghi, T. hirschmanni, T. irenae, T. lamda, T. minima, T. minimasimilis, T. mystacinus, T. pauperior and T. splendida) and characterised by their external morphology, geographic distribution and ecological requirements in terms of habitat preference, affinity to merocoenoses and vertical distribution. The zoogeographic origin of Trachytes is analysed. Most species are found only in woodlands and have not been recorded in the distribution area of the Pannonian flora in Central Europe (except for $T$. aegrota and $T$. baloghi). Short taxonomic remarks are given for the species of dubious taxonomic status or whose occurrence is not reliably known.
\end{abstract}

\section{INTRODUCTION}

There are up to 30 species of uropodine mites of the genus Trachytes Michael, 1894 described from Europe, of which 23 species are known from Central European countries including Germany, Czech Republic, Austria, Poland, Slovakia, Hungary, Ukraine and Romania (Table 1). This area is larger than Central Europe as conventionally defined. Of the mentioned countries the highest numbers of species were recorded in Romania (16) and Slovakia (10), and the lowest in Germany (4). Species of Trachytes are distributed mainly in the Palaearctic region and only 2 species are known from North America. This genus includes specialised edaphic detriticoles. Species of Trachytes make up the largest portion of the species in the Uropodina cohort living in the zooedaphon of forest habitats.

In Europe, several authors have studied the genus Trachytes. The most significant taxonomic data are in the papers of Hirschmann \& Zirngiebl-Nicol (1969), Pecina (1970a, 1970b, 1980), Zirngiebl-Nicol (1973), Huțu (1973, 1983) and Bloszyk (1980). Their papers also include some ecological notes on individual species, as do the general works on Uropodina (Huț, 1982; Błoszyk, 1984, 1999; Karg 1989).

Recently, the greatest problem was the registration of records of newly described species of Trachytes. Approximately $2 / 3$ of the species were described during $1970 \mathrm{~s}$ and $1980 \mathrm{~s}$. For example, the identification keys of Hirschmann \& Zirngiebl-Nicol (1965) included 13 species from the central part of Europe and the key to the fauna of the former Soviet Union (Kadite \& Petrova, 1977), which also included West European species, included 15 species. Later, the key of Karg (1989) published in "Die Tierwelt Deutschlands" included 20 species (the key presented in this paper includes 23 species).
The identification keys presented here use mainly diagnostic characters, which are used by other authors (Hirschmann \& Zirngiebl-Nicol, 1965; Kadite \& Petrova, 1977, Karg, 1989), and also new combinations of these characters and new characters. The key to deutonymphs includes the previously unknown deutonymphal stages of some species (T. baloghi, T. minima, T. minimasimilis, $T$. mystacinus and $T$. splendida). Keys were compiled only for females and deutonymphs because the larvae, protonymphs and males are rare and known for very few species. Diagnoses of individual species were compiled only for females because the deutonymphs are very uniform. Morphological terms and pattern of chaetotaxy (Fig. 1) used in this paper follow Hirschmann \& Zirngiebl-Nicol $(1965,1969)$.

\section{MATERIAL AND METHODS}

The examined specimens were collected by the quantitative methods and individual collecting in Slovakia during 1990-2002. The quantitative collection methods included the extraction of soil samples and the sifting of litter. Extraction of soil samples was used in consistent or seeped substrates like meadow soils, rhizosphere of grasses, fresh and wet dung, compost and decaying plant debris. Sifting was used to obtain the mites living in soil, leaf litter, moss, organic detritus from old decaying wood or ant-hills. The mites from the soil samples or from sifted detritus were extracted by a photothermoeclector (the Tullgren's apparatus).

The individual collecting was used to obtain mites living under bark, in decaying wood, under stones and pieces of wood, in ant-hills, on mushrooms etc. The mites were transferred by a pincette with wetted tips or brush into a test-tube with alcohol. To identification, the mites were mounted into permanent microscopic slides, using the Liquido de Swan.

\section{GENUS TRACHYTES MICHAEL, 1894}

Michael, 1894: 313.

Type species. Celaeno aegrota C. L. Koch, 1841 
TABLE 1. Occurrence of Trachytes species in countries of the central part of Europe.

\begin{tabular}{|c|c|c|c|c|c|c|c|c|}
\hline Species / Country & GER & CzE & Aus & PoL & SLO & Hun & UKR & RoM \\
\hline Trachytes aegrota (C. L. Koch, 1841) & + & + & + & + & + & + & + & + \\
\hline Trachytes arcuatus Hirschmann \& Zirngiebl-Nicol, 1969 & - & - & + & - & - & + & - & + \\
\hline Trachytes baloghi Hirschmann \& Zirngiebl-Nicol, 1969 & - & + & - & - & + & + & - & + \\
\hline Trachytes decui Huțu, 1983 & - & - & - & - & - & - & - & + \\
\hline Trachytes eustructura Hirschmann \& Zirngiebl-Nicol, 1969 & - & - & + & - & - & - & - & - \\
\hline Trachytes hiramatsui Huțu, 1983 & - & - & - & - & - & - & - & + \\
\hline Trachytes hirschmanni Huțu, 1973 & - & - & - & + & + & - & - & + \\
\hline Trachytes irenae Pecina, 1970 & - & + & + & + & + & - & + & + \\
\hline Trachytes lamda Berlese, 1904 & - & - & - & + & + & + & + & + \\
\hline Trachytes micropunctata Huțu, 1973 & - & - & - & - & - & - & - & + \\
\hline Trachytes minima Trägírdh, 1910 & - & + & - & + & + & - & + & - \\
\hline Trachytes minimasimilis Mašán, 1999 & - & - & - & + & + & - & - & + \\
\hline Trachytes montana Willmann, 1953 & - & + & + & + & - & - & + & - \\
\hline Trachytes mystacinus Berlese, 1910 & - & - & + & - & + & - & - & - \\
\hline Trachytes oudemansi Hirschmann \& Zirngiebl-Nicol, 1969 & + & - & - & - & - & - & - & + \\
\hline Trachytes pauperior (Berlese, 1914) & + & + & + & + & + & + & + & + \\
\hline Trachytes pecinai Huțu, 1983 & - & - & - & - & - & - & - & + \\
\hline Trachytes pi Berlese, 1910 & + & - & + & - & - & + & - & - \\
\hline Trachytes romanica Huțu, 1983 & - & - & - & - & - & - & - & + \\
\hline Trachytes splendida Huțu, 1973 & - & - & - & + & + & - & - & + \\
\hline Trachytes stammeri Hirschmann \& Zirngiebl-Nicol, 1969 & - & - & - & - & - & + & - & - \\
\hline Trachytes tuberifer Berlese, 1914 & - & - & + & - & - & - & - & - \\
\hline Trachytes wisniewskii Huțu, 1983 & - & - & - & - & - & - & - & + \\
\hline
\end{tabular}

Explanations: Ger - Germany, Cze - Czech Republic, Aus - Austria, Pol - Poland, Slo - Slovakia, Hun - Hungary, UkR Ukraine, Rom - Romania.

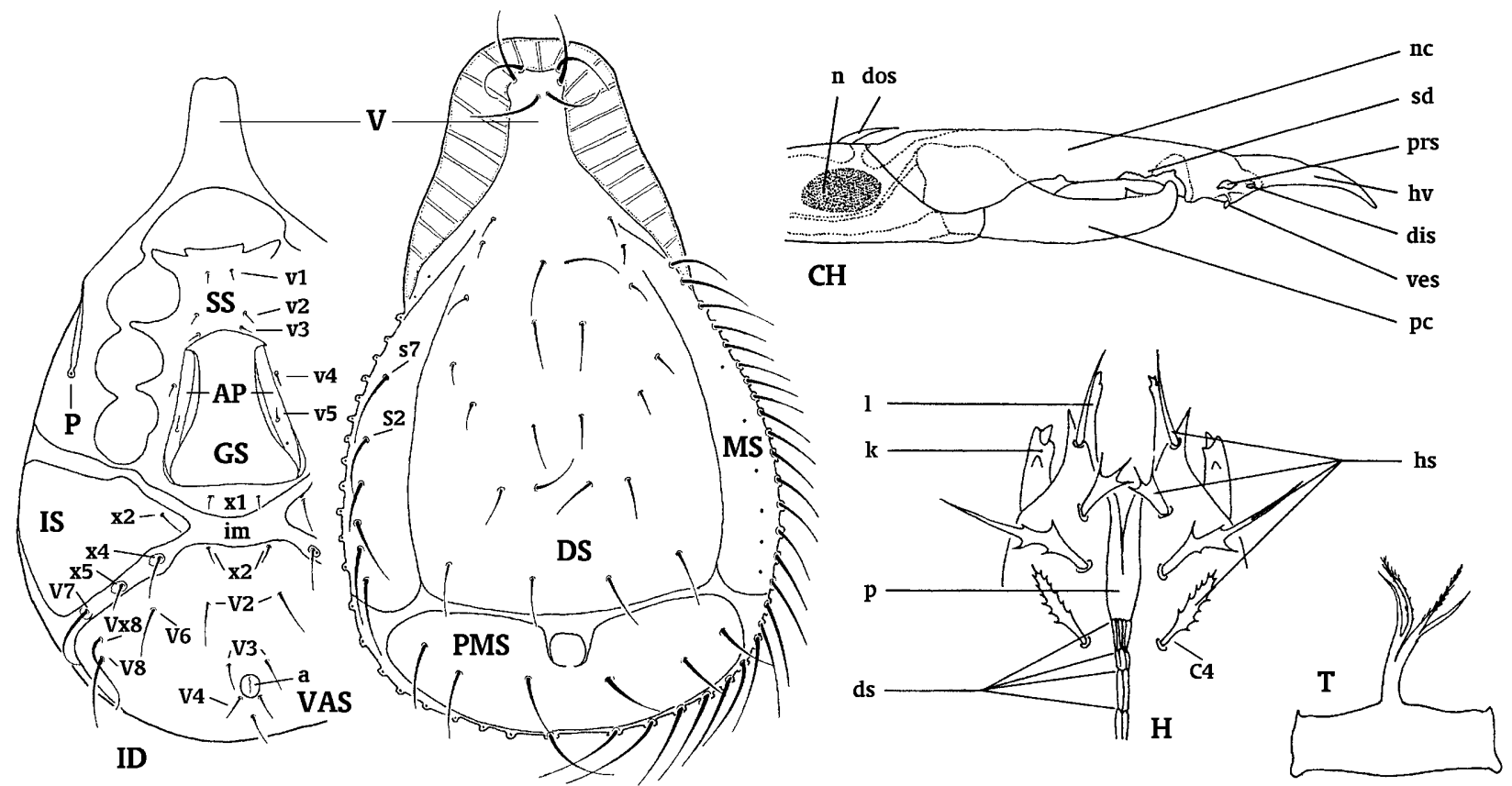

Fig. 1. Morphological terms and chaetotaxy used in diagnosis of Trachytes spp. and identification keys (a - anus, AP - adgenital platelets, $\mathrm{CH}$ - chelicera, dis - distal sensilla, dos - dorsal sensilla, DS - dorsal shield, ds - deuterosternal grooves, GS - genital shield, H - hypostome, hs - hypostomal setae C1-C4, hv - hyaline process, ID - ventrum and dorsum of idiosoma, im - interscutal membrane, IS - inguinal shield, $\mathrm{k}$ - cornicula, 1 - lacinia, MS - marginal shield, $\mathrm{n}$ - nodus, $\mathrm{nc}$ - unmoveable digit, $\mathrm{P}$ - peritreme, $\mathrm{p}$ protosternum, pc - moveable digit, PMS - postmarginal shield, prs - proximal sensilla, sd - serrula denticulata, SS - sternal shield, $\mathrm{T}$ - tritosternum, V - vertex, VAS - ventrianal shield, ves - ventral sensilla). 
Diagnosis. [According to Hirschmann (1993).]

Chelicera. Nodus absent. Digitus fixus with long, apically narrowed, mostly curved and pointed processus hyalinus; distal, proximal and ventral sensillae present. Serrula denticulata short. Digitus mobilis with seta-like sensillum mobile.

Ventral side of hypostome. Corniculae horn-like. Laciniae with 2 branches; shorter inner branch smooth, longer outer one covered by microdenticles on inner side or on whole surface. Protosternum narrow, broadened between coxal setae $\mathrm{C} 2-\mathrm{C} 3$, smooth or denticulated marginally. Deutosternum connected, with 2-3 transverse rows of small denticles (or with smooth furrows in males of some species) and some very short and fine longitudinal sculptural lines connected with bases of the denticles. Coxal setae C1, C2 and C3 simple, needle-like and smooth; C4 with small denticles marginally; $\mathrm{C} 1$ and $\mathrm{C} 3$ long, $\mathrm{C} 2$ short to medium, C4 shortest; C2 and C3 adjacent, C4 situated laterally near to hypostome margin.

Epistom. Unipartite, spear-shaped process. Basal part denticulated or shortly thorned marginally. Distal part with finely microdenticulated areas or microdenticles situated only marginally.

Tritosternum. Basal part wide, rectangular, smooth and with a little tooth in anterolateral angles. Basal part of laciniae smooth, divided into 4 branches; inner branches fine denticulated and longer than smooth outer ones.

Idiosoma. Flat, pear-like and oblong. Dorsum of adults with dorsal shield situated medially, 2 marginal shields situated laterally and postmarginal (pygidial) shield situated posteromarginally. Ventrum of females either with holoventral shield or with anterior sternal shield, 2 lateral inguinal shields and posterior ventrianal shield separated by interscutal membrane. Dorsal and ventral setae simple, needle-like and mostly smooth.

\section{KEY TO THE FEMALES OF TRACHYTES FROM THE CENTRAL PART OF EUROPE}

1(34)Holoventral shield absent: ventrum divided into sternal, ventrianal and inguinal shields and separated by interscutal membranes (Figs 2, 4, 7, 9, 11, 13).

2(23)Anterolateral angles of genital shield pointed, points directed laterally (Figs 7, 9, 11, 13).

3(6)Line connecting bases of sternal setae v2 and v3 perpendicular to longitudinal body axis, setae $v 2$ and $v 3$ adjacent and situated beside each other in front of anterior margin of genital shield (Figs 7, 13).

4(5)Vertex with broad and ribbed lateral parts; genital shield distinctly sculptured with oval pores medially and laterally, posterior margin of genital shield convex; larger species, length of idiosoma: $680-700 \mu \mathrm{m}$ Trachytes baloghi Hirschmann \& Zirngiebl-Nicol, 1969 (Figs 7-8)

5(4)Vertex without broad and ribbed lateral parts; genital shield without distinct sculpture (only micropores present laterally), posterior margin of genital shield concave; smaller species, length of idiosoma: $460-490 \mu \mathrm{m} . \ldots .$.

. . Trachytes pauperior Berlese, 1914 (Figs 13-14)

6(3)Line connecting bases of sternal setae $v 2$ and $v 3$ parallel or oblique to longitudinal body axis, setae $\mathrm{v} 2$ situated between setae v1 and v3 (Figs 9, 11).

7(10)Ventrianal shield with setae $\times 3$ (Fig. 9).
8(9)Lateral parts of vertex distinctly broadened and ribbed; length of idiosoma: 650-700 $\mu \mathrm{m}$

Trachytes aegrota C. L. Koch, 1841 (Figs 9-10)

9(8)Vertex without broad and ribbed lateral parts; length of idiosoma: $615 \mu \mathrm{m}$

Trachytes oudemansi Hirschmann \& Zirngiebl-Nicol, 1969

10(7)Ventrianal shield without setae $\times 3, x 3$ situated on small oval platelets or on interscutal membrane in front of ventrianal shield (Fig. 11).

11(12)Interscutal membrane in front of ventrianal shield with additional pair of $\mathrm{x}$ setae $(\mathrm{x} 5)$; genital shield with net-like sculpture medially; length of idiosoma: $670-720 \mu \mathrm{m} \ldots$.

Trachytes pi Berlese, 1910

12(11)Additional pair of $\times 5$ setae on interscutal membrane absent; genital shield without net-like sculpture (sculpture otherwise formed).

13(14)Inguinal shields partially fused with exopodal and ventrianal shields on lateral part of ventrum; length of idiosoma: $730 \mu \mathrm{m}$.......... Trachytes montana Willmann, 1953

14(13)Inguinal shields fully separated from exopodal and ventrianal shield by interscutal membrane (Fig. 11, 13).

15(18)Inguinal shields with setae x4 (Fig. 4); interscutal membrane between ventral shields narrow; postgenital part of sternum slightly prolonged; genital shield with strong porelike sculpture.

16(17)Setae v5 pilose and 5-6 times longer than other sternal setae; ventrianal shield with strong wart-like sculpture; length of idiosoma: $635-655 \mu \mathrm{m} \ldots \ldots \ldots \ldots \ldots$ ... . . . . . . . . . Trachytes romanica Huțu, 1983

17(16)All sternal setae of approximately equal length and smooth; ventrianal shield finely granulated; length of idiosoma: $670-700 \mu \mathrm{m}$... . . Trachytes hiramatsui Huțu, 1983

18 (15)Inguinal shields without setae $\mathrm{x} 4, \mathrm{x} 4$ situated on interscutal membrane or on platelets (Figs 7, 9, 11); interscutal membrane between ventral shields wide; postgenital part of sternum slightly shortened; genital shield without sculpture or with fine micropores.

19(20)Dorsal shield with dense wart-like sculpture; lateral margins of vertex distinctly broad and with 9-11 long ribs; length of idiosoma: $760-780 \mu \mathrm{m} \ldots \ldots \ldots \ldots \ldots$

. . . . . . . . . . . . . Trachytes pecinai Huțu, 1983

20(19)Dorsal shield sculptured with small pores or micropores; lateral margins of vertex narrow or slightly broadened and with 4-6 short ribs (Fig. 11).

21(22)Vertex without broad lateral margins, narrow; dorsal and genital shield sculptured with micropores; length of idiosoma: 600-630 $\mathrm{mm} \mathrm{...} \mathrm{.} \mathrm{Trachytes} \mathrm{wisniewskii} \mathrm{Huț,} 1983$

22(21)Vertex with slightly broad lateral margins each bearing 4-6 short ribs; dorsal shield sculptured with larger rounded circlets, genital shield smooth and without sculpture; length of idiosoma: $590-600 \mu \mathrm{m}$

Trachytes hirschmanni Huțu, 1973 (Figs 11-12)

23(2)Anterolateral angles of genital shield regularly rounded, without points (Figs 2, 4, 5).

24(27)Outer lateral sides of adgenital platelets formed into sailshaped prominences.

25(26)Margin of adgenital sail-shaped prominences regularly rounded; sternal setae v1-v5 of equal length; setae $\mathrm{x} 3$ and $\mathrm{x} 4$ situated on small oval platelets; length of idiosoma: $620-625 \mu \mathrm{m} \quad \ldots . . \ldots \ldots$. . . Trachytes decui Huțu, 1983

26(25)Margin of adgenital sail-shaped prominences apically pointed; setae v5 2-3 times longer than other sternal setae; setae $x 3$ and $\times 4$ situated on interscutal membrane; length of idiosoma: $630-650 \mu \mathrm{m}$

$$
\text { Trachytes micropunctata Huțu, } 1973
$$

27(24)Adgenital platelets of typical form (Figs 2, 4). 
28(29)Anterior margin of genital shield widely rounded, equal in size to posterior margin and with net-like sculpture; length of idiosoma: $560 \mu \mathrm{m}$

Trachytes lamda Berlese, 1903 (Figs 2-3)

29(28)Anterior margin of genital shield distinctly narrower (1.5-2 times) than posterior one; genital shield otherwise sculptured (Fig. 4).

30(31)Anterior margins of adgenital platelets reach sternal setae $\mathrm{v} 3$; length of idiosoma: $700 \mu \mathrm{m}$ ................ Trachytes tuberifer Berlese, 1914

31(30)Anterior margins of adgenital platelets reach sternal setae $\mathrm{v} 4$ or area between setae $\mathrm{v} 3$ and $\mathrm{v} 4$; inguinal shields with ventral setae $x 4$ (Fig. 4)

32(33)Ventral setae V7, Vx7, V8 and Vx8 2-2.5 times longer than setae $\mathrm{x} 2$, $\mathrm{x} 3$ a x4; length of idiosoma: $695-735 \mu \mathrm{m} .$. .

........ Trachytes mystacinus Berlese, 1910 (Figs 4-6)

33(32)Ventral setae V7, Vx7, V8, Vx8, x2, x3 and $\mathrm{x} 4$ of approximatelly the same length; length of idiosoma: $685 \mu \mathrm{m}$

Trachytes arcuatus Hirschmann \& Zirngiebl-Nicol, 1969

34(1)Solid holoventral shield present (Figs 15, 17, 19, 21).

35(38)Metapodal region with flower-like sculpture (Figs 19, 21 ); larger species with length of idiosoma more than 650 $\mu \mathrm{m}$.

36(37)Anterior margin of sternum smooth, without sculpture; genital shield with convex lateral margins and anterolateral points directed laterally, sculptured with small oval pores posteriorly; wider adgenital platelets; length of idiosoma: $680-780 \mu \mathrm{m}$...........................

Trachytes irenae Pecina, 1970 (Figs 19-20)

37(36)Anterior margin of sternum strongly sculptured (ring-like form and 2 oblique ribs present); genital shield with straight lateral margins and anterolateral points directed anteriorly, sculptured with large irregular pores anteriorly; narrower adgenital platelets; length of idiosoma: $730-750 \mu \mathrm{m} \ldots$...

Trachytes splendida Huțu, 1973 (Figs 21-22)

38 (35)Metapodal region with net-like or pore-like sculpture (Figs 15, 17); smaller species with length of idiosoma under $600 \mu \mathrm{m}$.

39(42)Tips of marginal setae s7 not reaching bases of setae S2 (Figs 16, 18).

40(41)Anterior margin of sternum with bow-like sculpture; length of idiosoma: $500-540 \mu \mathrm{m}$

....... Trachytes minima Trägårdh, 1910 (Figs 15-16)

41(40)Anterior margin of sternum with ball-like sculpture; length of idiosoma: $510-575 \mu \mathrm{m}$

Trachytes minimasimilis Mašán, 1999 (Figs 17-18)

42(39)Tips of marginal setae $\mathrm{s} 7$ reach or exceed bases of setae S2 (Fig. 6)

43(44)Tips of ventral setae V2 not reaching bases of setae V3; tips of dorsal setae 13 not reaching posterior margin of dorsal shield; pregenital area without distinct sculpture; length of idiosoma: $455 \mu \mathrm{m} \ldots \ldots \ldots \ldots \ldots \ldots$ Trachytes eustructura Hirschmann \& Zirngiebl-Nicol, 1969

44(43)Tips of ventral setae V2 exceed bases of setae V3; tips of dorsal setae I3 exceed dorsal shield posteriorly; pregenital area densely sculptured with larger pores; length of idiosoma: $560 \mu \mathrm{m}$

Trachytes stammeri Hirschmann \& Zirngiebl-Nicol, 1969

\section{KEY TO THE DEUTONYMPHS OF TRACHYTES FROM THE CENTRAL PART OF EUROPE}

1(10)Ventrianal shield oval and with anus located near to its posterior margin; ratio of length to width of ventrianal shield between 1:2 to 3:5 (Figs 23, 25, 28, 30-31).
2(3) Sternal shield between setae v1 and v2 with short lateral incisions and net-like sculpture; larger species, length of idiosoma: $590-670 \mu \mathrm{m}$ ........... Trachytes splendida Hutu, 1973 (Fig. 30)

3(2)Sternal shield between setae v1 and v2 with straight lateral margins and without net-like sculpture medially (only small pores present; Figs 23, 25, 28, 31); smaller species, length of idiosoma under $550 \mu \mathrm{m}$.

4(7)Sternal shield between setae v2 and v3 with irregular porelike sculpture (Figs 25, 31).

5(6)Sternal shield between setae v4 and v5 with fine net-like sculpture; ratio of length to width of ventrianal shield approximately $3: 5$; larger species, length of idiosoma: $435-485 \mu \mathrm{m}$

Trachytes minimasimilis Mašán, 1999 (Fig. 25)

6(5)Sternal shield between setae $v 4$ and v5 with fine pore-like sculpture; ratio of length to width of ventrianal shield approximately $1: 2$; smaller species, length of idiosoma:

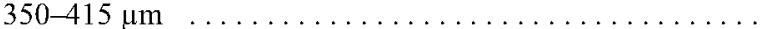

Trachytes pauperior Berlese, 1914 (Fig. 31)

7(4)Sternal shield between setae v2 and v3 sculptured with pores regularly associated in flower-like clusters (Figs 23, 28).

8(9)Sternal shield posterior of setae v1 with fine net-like sculpture; anal shield slightly oval and granulated with irregularly formed pores; length of idiosoma: $410-475 \mu \mathrm{m}$

Trachytes minima Trägårdh, 1910 (Fio 23)

9(8)Sternal shield posterior of setae v1 with 2 pairs of large pores laterally; anal shield slightly triangular and sculptured with regularly rounded pores; length of idiosoma: $480-530 \mu \mathrm{m}$.... Trachytes lamda Berlese, 1903 (Fig. 28)

10 (1)Ventrianal shield rounded and with anus located medially; ratio of length to width of ventrianal shield between $3: 5$ and 3:4 (Figs 24, 26-27, 29).

11(12)Sternal shield at the level of stae $v 1$ or between setae v1 and v2 slightly broadened or with straight lateral margins; sternal shield between its anterior margin and setae v1 with 2 large oval pores; length of idiosoma: $555-670 \mu \mathrm{m} . . .$. .

Trachytes irenae Pecina, 1970 (Fig. 29)

12(11)Sternal shield at the level of stae $v 1$ or between setae v1 and v2 narrowed; sternal shield between its anterior margin and setae v1 without large pores (Figs 24, 26-27).

13(14)Anteromedial margin of anal shield with distinct oval pores; sternal shield between its anterior margin and setae v1 with curved sculptural line; sternal shield between setae $\mathrm{v} 1$ and v2 with fine net-like sculpture; length of idiosoma:

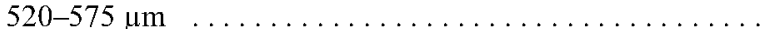
Trachytes baloghi Hirschmann \& Zirngiebl-Nicol, 1969 (Fig. 24)

14(13)Anteromedial margin of anal shield without distinct sculpture or with isolated small pores; sternal shield between its anterior margin and setae v1 without sculptural lines; sternal shield between setae v1 and v2 sculptured otherwise (Figs 26-27).

15(16)Sternal shield between setae v1 and v2 sculptured with micropores or occasionally with 2 large oval pores; sternal shield between setae v2 and v3 sculptured with fine pores laterally; length of idiosoma: $530-630 \mu \mathrm{m}$

Trachytes aegrota C. L. Koch, 1841 (Fig. 26)

$16(15)$ Sternal shield between setae v1 and v2 sculptured with 3-6 subtriangular pores; whole sternal shield between setae v2 and v3 sculptured with fine pores; length of idiosoma: $550-625 \mu \mathrm{m}$

Trachytes mystacimus Berlese, 1910 (Fig. 27) 


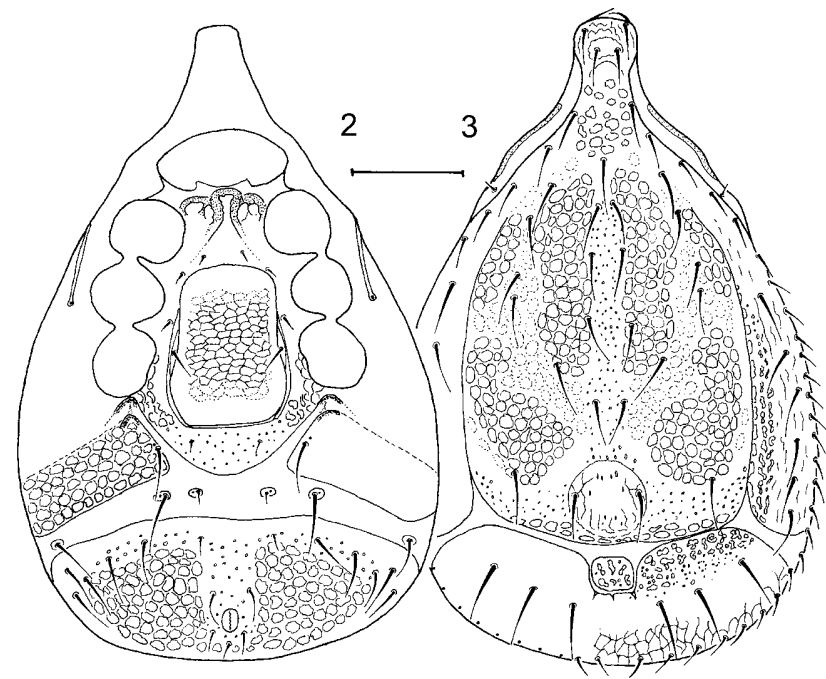

Figs 2-3. Trachytes lamda (q). 2 - ventral view; 3 - dorsal view. Scale: $100 \mu \mathrm{m}$.

\section{LIST OF SPECIES RECORDED FROM SLOVAKIA}

\section{Trachytes lamda Berlese, 1904}

(Figs 2-3, 28)

Trachytes lamda Berlese, 1903: 272; Athias-Binche, 1980: 47; Błoszyk \& Olszanowski, 1985: 314; Błoszyk, 1999: 122; Mašán, 2000: 63.

Trachytes lambda Berlese, 1914: 135; Hirschmann \& ZirngieblNicol, 1964: 19, 1965: 14, 1969: 128; Zirngiebl-Nicol, 1973: 13; Błoszyk, 1980: 33

Diagnosis. Female. Vertex without broad lateral margins. Dorsal shield strongly sculptured with large and irregularly rounded circlets. Posterior marginal setae short, approximately $1 / 3$ length of postmarginal setae. Solid holoventral shield absent. Wide belts of ventral interscutal membrane present. Anterior part of sternal area with 3 strongly sclerotized ring-like forms. Sternal setae v1 shortest (not easily visible) and v5 longest; line connecting bases of v2 and v3 setae oblique to longitudinal body axis. Genital shield oblong, wide, with straight posterior and slightly curved anterior margin, with rounded anterolateral angles and distinct net-like sculpture medially. Narrow adgenital platelets present. Ventrianal and inguinal shields distinctly sculptured with irregular and large circlets. Ventral setae $x 3$ and $x 4$ placed on small oval platelets situated on interscutal membrane; setae x1, x3 and V2 shortest and of equal size.

Distribution. France, Poland, Slovakia, Hungary, Ukraine, Romania and Italy.

Habitat. Edaphic detriticole. In Slovakia a stenotopic species with discontinuous distribution and local occurrence (Fig. 32). Probably a calciphilous species preferring deciduous forests growing in limestone areas. Most abundant in maple-beech forests and in deciduous forests dominated by beech. Vertically distributed at middle altitudes from 450 to $950 \mathrm{~m}$ a. s. 1 .

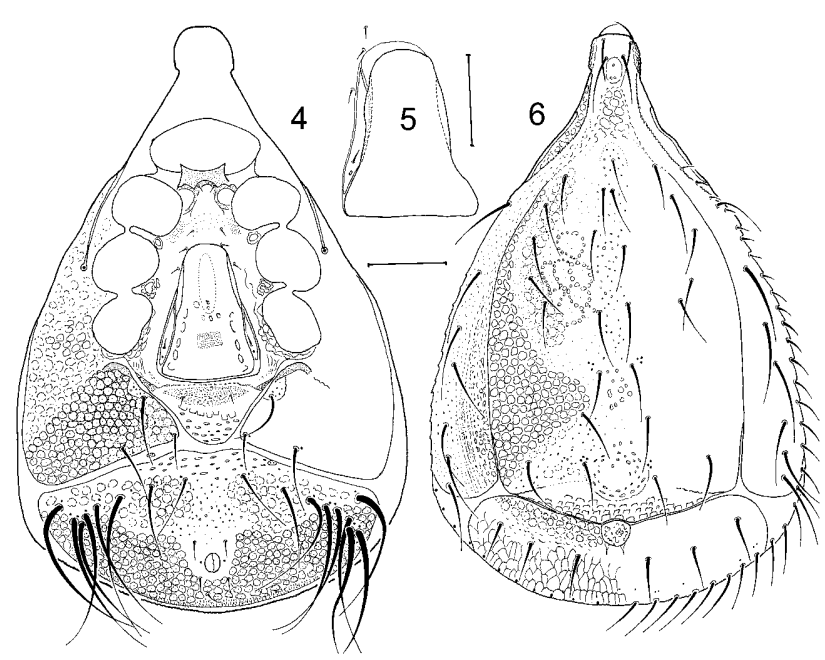

Figs 4-6. Trachytes mystacinus (\%). 4 - ventral view; 5 genital and adgenital shield in detail; 6 - dorsal view. Scale: $100 \mu \mathrm{m}$.

\section{Trachytes mystacinus Berlese, 1910}

(Figs 4-6, 27)

Trachytes mystacinus Berlese, 1910: 377, 1914: 135; Hirschmann \& Zirngiebl-Nicol, 1964: 19, 1965: 15, 1969: 128; Zirngiebl-Nicol, 1973: 13; Mašán, 2000: 64.

Trachytes mystiacus Schweizer, 1961: 176.

Diagnosis. Female. Vertex without broad lateral margins. Dorsal shield sculptured with irregularly rounded circlets and pores. Posterior marginal setae long, approximately the same length as postmarginal setae. Submarginal setae long and with tips that reach far beyond the bases the next setae. Solid holoventral shield absent. Narrow belts of interscutal membrane present. Anterior part of sternal area strongly sclerotized and with 1 planklike and 2 ring-like forms. Sternal setae v1-v5 of equal size; line connecting bases of v2 and v3 setae approximately parallel to longitudinal body axis. Genital shield oblong, subtriangular, with straight or slightly concave posterior margin and regularly rounded anterior margin, without anterolateral points and with oval pores situated laterally (in some specimens also medially). Anterior part of adgenital platelets covered by genital shield and with fore margin situated between sternal setae v3 and v4. Postgenital shield long and sculptured with oval pores like anterior part of ventrianal shield. Ventrianal and inguinal shields with dense flower-like sculpture of irregular rounded circlets. Ventral setae $\mathrm{x} 1$ shorter than x3 (app. 1/4-1/6), x3 shorter than V2 (app. 1/2); setae x3 and $x 4$ on inguinal shields or in some specimens setae $x 3$ are on small oval platelets on interscutal membrane. Lateral ventrianal setae considerably thickened and prolonged and with tips reaching far beyond posterior margin of idiosoma.

Distribution. Slovakia, Austria, Switzerland and Italy.

Habitat. An edaphic detriticole with little known about its ecology. The old original records were poorly documented. This species is recorded in Slovakia only from 


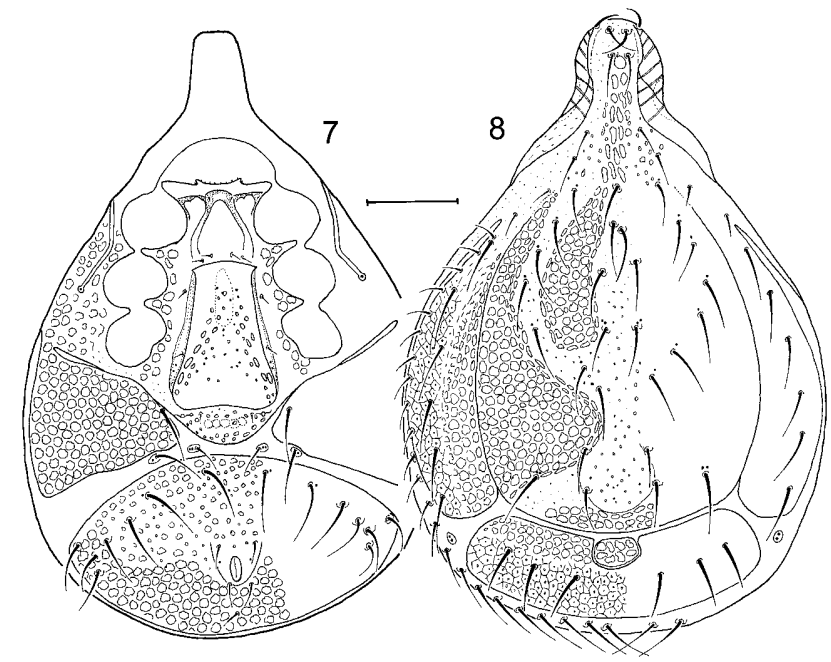

Figs 7-8. Trachytes baloghi (ㅇ). 7 - ventral view; 8 - dorsal view. Scale: $100 \mu \mathrm{m}$.

mountain ranges in the western part of the country (Fig. 32 ), where it is not rare in leaf litter. It is obvious that the north-eastern border of its distribution runs through Slovakia. In Slovakia it prefers beech forests on southerly exposed slopes, but also occurs abundantly in oak forests with beech. Vertical distribution of this species ranges from 370 to $950 \mathrm{~m}$ a. s. 1., with the optimum between 400 and $600 \mathrm{~m}$ a.s. 1 .

Remarks. The diagnoses of females of $T$. mystacinus and T. tuberifer, which are known only from the little detail in the old original descriptions and drawings, were based on the form and length of adgenital platelets, which are longitudinally situated along the lateral margins of their genital shields (see key). The fore part of the genital shield in T. mystacinus is moderately enlarged due to laterally attached wing-like plates, which anteriorly overlap the adgenital platelets (Fig. 5). This overlap makes the observation of whole adgenital platelets difficult or impossible. Thus, inevitablely the specimens are damaged during identification. The adgenital platelets in Slovak populations of $T$. mystacinus reach the maximum length given in identification keys for distinguishing T. mystacinus from $T$. tuberifer.

\section{Trachytes baloghi Hirschmann \& Zirngiebl-Nicol, 1969}

(Figs 7-8, 24)

Trachytes baloghi Hirschmann \& Zirngiebl-Nicol, 1964: 19 (i. 1.), 1965: 15 (i. 1.), 1969: 39; Mašán, 2000: 66.

Trachytes tesquorum Pecina, 1980: 402 (syn. n.).

Diagnosis. Female. Vertex with broad lateral margins; lateral margins with 5-9 transverse ribs. Dorsal shield strongly sculptured with large and irregularly rounded circlets. Posterior marginal setae long, approximately the same length as postmarginal setae. Solid holoventral shield absent. Anterior part of sternal area with strongly sclerotized band-like forms extending posteriorly to sternal setae v2 and v3. Sternal setae v1 very short (not easily visible) and setae v2-v5 of equal size; line con- necting bases of adjacent v2 and v3 setae approximately perpendicular to longitudinal body axis. Genital shield oblong, with slightly curved lateral margins and anterolateral points directed laterally, sculptured with oval pores and micropores laterally. Posterior part of ventrianal shield and inguinal shields strongly sculptured with large irregularly rounded circlets. Ventrianal shield with regularly rounded anterior margin and smaller structural pores anteriorly. Ventral setae $\mathrm{x} 1$ shorter than $\mathrm{x} 3$ (app. 1/3-1/4), x3 shorter than V2 (app. 1/2 times); setae x3 and $\mathrm{x} 4$ placed on small oval platelets situated on interscutal membrane.

Distribution. Slovakia, Hungary and Romania.

Habitat. An edaphic detriticole, originally described from Hungary. The northern border of the distribution of T. baloghi runs through Slovakia (Fig. 32) as it is not found in Poland. In Slovakia it inhabits exclusively warm relatively dry localities in lowlands and low highlands (up to $400 \mathrm{~m}$ a. s. 1., with the optimum ranging from 250 to $350 \mathrm{~m}$. a. s. 1.). Such a distribution is, however, atypical of the Trachytes species. Most abundantly recorded in leaf litter of xerophilous oak forests, but also frequently recorded in samples from forest-steppe, from xerothermic meadows at the margins of oak forests, where the grass rhizosphere is its natural microhabitat. It was also occassionally recorded in horn beam-oak forests and in oak stands with pines or locust trees. It is probably an element of the Mediterranean fauna.

Remarks. T. tesquorum Pecina, 1980 was originally described from xerothermic habitats in Slovakia, which are typical of T. baloghi. Examination of the topotypical material from the Kováčovské kopce hills showed $T$. tesquorum to be synonymous with $T$. baloghi. The similarity of these species, with the exception of the lengths of some dorsal and ventral setae, is obvious from the original drawings by Pecina (1980). The revised specimens from Romania, which were identified as $T$. tesquorum (leg. et det. M. Huțu), also belong to $T$. baloghi.

\section{Trachytes aegrota (C. L. Koch, 1841)}

(Figs 9-10, 26)

Celaeno aegrota C. L. Koch, 1841: 32; Berlese, 1887: 38.

Trachynotus pyriformis Kramer, 1876: 74.

Trachytes pyriformis Michael, 1894: 313.

Trachytes aegrota Michael, 1894: 313; Hirschmann \& Zirngiebl-Nicol, 1961: 10, 1964: 19, 1965: 15, 1969: 128; Pecina, 1970a: 423, 1970b: 44; Zirngiebl-Nicol, 1973: 11; Pecina, 1980: 393; Błoszyk, 1980: 29; Athias-Binche, 1980: 46; Błoszyk \& Olszanowski, 1985: 314; Karg, 1989: 69; Błoszyk, 1999: 116; Mašán, 2000: 69.

Diagnosis. Female. Vertex with very broad lateral margins, lateral margins with 8-13 transverse ribs. Dorsal shield weakly sculptured with round circlets and pores; groups of light reflecting pores present near to bases of dorsal setae. Posterior marginal setae long, approximately 1.5 times longer than postmarginal setae. Solid holoventral shield absent. Anterior part of sternal area with 3 


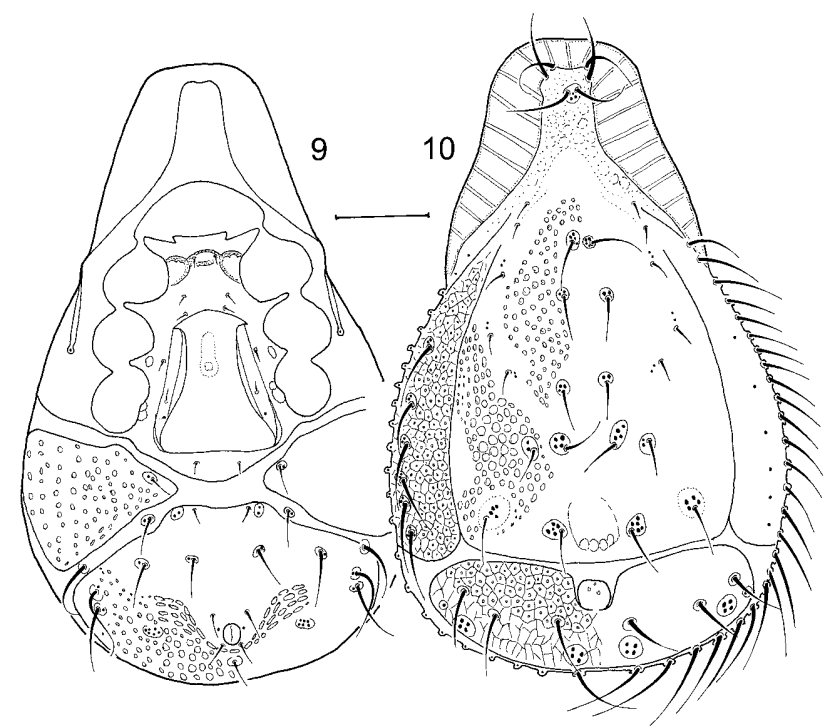

Figs 9-10. Trachytes aegrota (q). 9 - ventral view; $10-$ dorsal view. Scale: $100 \mu \mathrm{m}$.

weakly sclerotized ring-like forms. Sternal setae v1-v5 of equal size; line connecting bases of v2 and v3 setae approximately parallel to longitudinal body axis. Genital shield oblong, smooth and without sculpture, with distinctly curved lateral margins and large anterolateral points directed laterally. Wide adgenital platelets present. Posterior part of ventrianal shield and inguinal shields weakly sculptured with round and oval pores. Anterior part of ventrianal shield without sculpture. Ventral setae $\mathrm{x} 1$ and $\mathrm{x} 3$ of aproximately equal size and 3 times shorter than V2 setae; setae $\mathrm{x} 3$ situated on ventrianal shield and $\mathrm{x} 4$ on small oval platelets on interscutal membrane.

Distribution. Europe (in all Central European countries), Central Asia (Mongolia) and North America (USA).

Habitat. Edaphic detriticole. The most common and widely distributed representative of the Uropodina cohort in Slovakia (Fig. 32). It has a wide ecological tolerance and inhabits various habitats (Table 2) and microhabitats. As the only species of the Trachytes genus in Slovakia, it is continuously distributed from the lowlands up to the alpine zone $(2,150 \mathrm{~m}$ a. s. 1.), but most abundantly from 400 to $1,100 \mathrm{~m}$ a. s. 1 . This species is most abundant in homogenous beech and beech-fire forests, and common in old spruce forests. It is the eudominant component of the Uropodina communities in litter in dwarf pine stands. In contrast, it is less common in thermophilous oak forests, forest-steppe stands, locust tree stands and softwood floodplain forests.

Remarks. The material of this species examined rarely included specimens that lacked wide lamelar armature on vertex. Such specimens would be identified as $T$. oudemansi, which is characterised by the vertex lacking broad lateral margins (lamelar armature), but its other morphological characters are "almost" identical with those of $T$. aegrota. Therefore, that $T$. oudemansi is synonymous with $T$. aegrota may be justified.

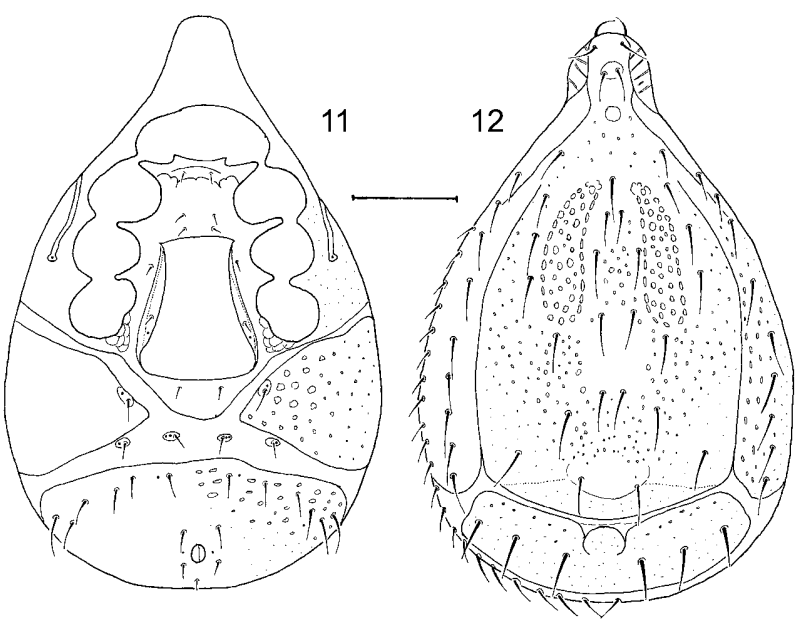

Figs 11-12. Trachytes hirschmanni (\$). 11 - ventral view; 12 - dorsal view. Scale: $100 \mu \mathrm{m}$.

\section{Trachytes hirschmanni Huțu, 1973}

(Figs 11-12)

Trachytes hirschmanni Huțu, 1973: 46.

Trachytes montana Willmann, 1953 sensu Błoszyk, 1980: 40, 1999: 126; Mašán, 2000: 71.

Diagnosis. Female. Vertex with slightly broad lateral margins; lateral margins with 3-6 transverse ribs. Dorsal shield weakly sculptured with small round pores (mostly anteromedially) and micropores. Posterior marginal setae short, approximately $1 / 2$ length of postmarginal setae. Solid holoventral shield absent. Wide belts of interscutal membrane present. Anterior part of sternal area weakly sclerotized and without conspicuous sculpture (only lines present). Sternal setae v1-v5 of equal size; line connecting bases of v2 and v3 setae approximately parallel to longitudinal body axis. Genital shield oblong, with regularly curved lateral margins and with anterolateral points directed laterally, without sculpture. Anterior part of ventrianal and inguinal shields weakly and thinly sculptured with oval and round pores. Ventral setae $x 1$ and $x 3$ of aproximately equal size and only slightly longer than V2 setae; setae $\mathrm{x} 3$ and $\mathrm{x} 4$ situated on small oval platelets on interscutal membrane.

Distribution. Poland, Slovakia, Ukraine and Romania.

Habitat. Edaphic detriticole. A rare representative of Central European fauna of Uropodina because of its atypical ecology. It is adapted to life in montane to alpine habitats especially the subalpine and alpine zone. In Slovakia it is found at the altitudes between 1,600 and 2,000 $\mathrm{m}$ a. s. 1., where it inhabits mainly litter in dwarf pine stands and probably also the rhizosphere of different species of grass (Fig. 32). It was also found in the stands of willows (Salix sp.) along the bank of a brook. According to Błoszyk (1999), it is also found at lower altitudes in Poland (above $1,100 \mathrm{~m}$ a. s. 1.). Probably a Carpathian endemic.

Remarks. This species is frequently confused with $T$. montana, which is known from the Alps and from some mountain ranges in Bohemia. 
TABLE 2. Occurrence and abundance of Trachytes species in soil detritus and litter in some habitats (phytocoenoses) in Slovakia.

\begin{tabular}{lllllllllllll}
\hline Species/Habitats & I. & II. & III. & IV. & V. & VI. & VII. & VIII. & IX. & X. & XI. & XII. \\
\hline Trachytes aegrota & + & + & - & + & ++ & + & ++ & +++ & +++ & +++ & +++ & +++ \\
Trachytes baloghi & - & - & - & - & + & +++ & ++ & + & - & - & - & - \\
Trachytes hirschmanni & - & - & - & - & - & - & - & - & - & - & - & + \\
Trachytes irenae & - & - & - & - & - & - & - & - & ++ & ++ & +++ & ++ \\
Trachytes lamda & - & - & - & - & - & - & - & + & ++ & - & - & - \\
Trachytes minima & - & - & - & - & - & - & - & - & ++ & - & - & - \\
Trachytes minimasimilis & - & - & - & - & - & - & - & - & + & - & - & - \\
Trachytes mystacinus & - & - & - & - & - & - & + & + & ++ & - & - & - \\
Trachytes pauperior & - & - & + & - & - & - & + & + & +++ & ++ & +++ & ++ \\
Trachytes splendida & - & - & - & - & - & - & - & - & + & + & - & -
\end{tabular}

Explanations: I. - arable lands, II. - meadows and ruderals, III. - pine forests in lowlands and foothills, IV. - soft-wood floodplain forests (willow-poplar stands), V. - hard-wood floodplain forests, VI. - xerothermophilous steppe and forest steppe-like habitats, VII. - oak forests, VIII. - hornbeam and oak-hornbeam forests, IX. - beech and ash-beech forests, X. - fir-beech forests, XI. montane (Norway) spruce forests, XII. - dwarf pine forests; +++ - very abundant, ++ - common, +- rare, -- not found.

\section{Trachytes pauperior (Berlese, 1914)}

(Figs 13-14, 31)

Trachytes pi var. pauperior Berlese, 1914: 135.

Trachytes pauperior Schweizer, 1961: 175; Hirschmann \& Zirngiebl-Nicol, 1964: 19, 1965: 15; 1969: 128; Pecina, 1970b: 56; Zirngiebl-Nicol, 1973: 11; Pecina, 1980: 401; Błoszyk, 1980: 31; Błoszyk \& Olszanowski, 1985: 314; Karg, 1989: 69; Błoszyk, 1999: 120; Mašán, 2000: 73.

Diagnosis. Female. Vertex without broad lateral margins. Dorsal shield strongly sculptured with large pentagonal and hexagonal pores; these pores with micropunctures marginally (similarly ventrally). Posterior marginal setae short, approximately $2 / 3-1 / 2$ length of postmarginal setae. Solid holoventral shield absent. Wide belts of interscutal membrane present. Anterior part of sternal area with 2 sclerotized ring-like forms. Sternal setae v1-v 5 of equal size; line connecting bases of v2 and v3 setae approximately perpendicular to longitudinal body axis. Genital shield relatively large, slightly prolonged, oblong, with approximately straight lateral mar-

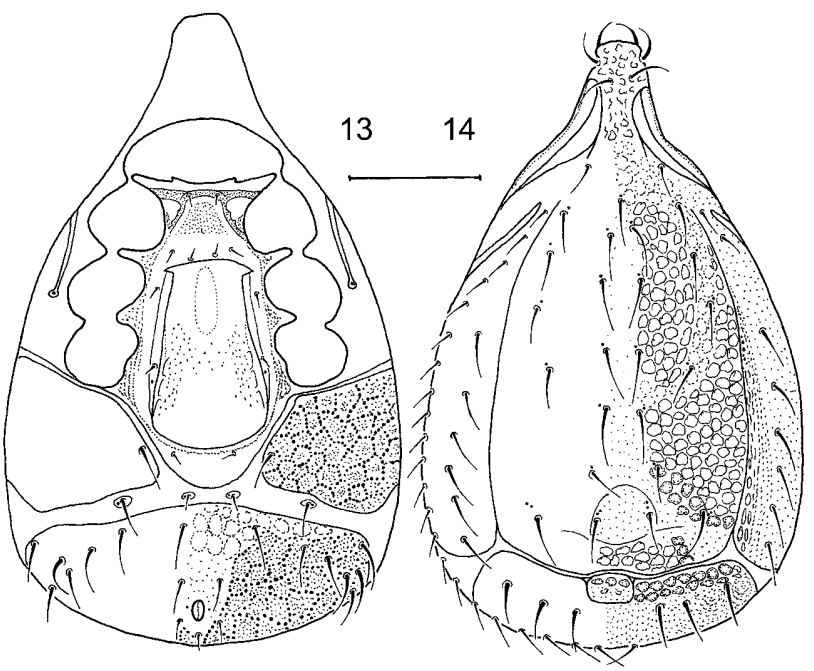

Figs 13-14. Trachytes pauperior ( $($ ). 13 - ventral view; 14 dorsal view. Scale: $100 \mu \mathrm{m}$. gins and regularly rounded posterior margin, with large anterolateral points directed laterally; sculpture absent or of micropores situated laterally. Ventrianal and inguinal shields with net-like sculpture similar to dorsum. Ventral setae $x 1$ and $x 3$ of aproximately equal size and $1 / 3-1 / 4$ length of setae V2; setae $x 3$ and $x 4$ situated on small oval platelets on interscutal membrane.

Distribution. Europe (in all Central European countries), Siberia.

Habitat. Edaphic detriticole. It is found mostly in forests at middle and higher altitudes and is absent in the lowlands and areas with Pannonian flora (Fig. 32). It has a wide ecological tolerance. It is most abundant in Slovakia at altitudes between 600 and $1,800 \mathrm{~m}$ a. s. 1., with a vertical distribution of between 200 and $2,150 \mathrm{~m}$ a. s. 1 . Because of its ecological plasticity, this species can be found in both deciduous and coniferous forests, which is rare in Trachytes species. For example, the abundance of T. pauperior in beech stands is similar to that in spruce monocultures. Its abundance in mixed forests was, as a rule, lower. This species is well represented in the litter of dwarf pine stands.

\section{Trachytes minima Trägårdh, 1910}

(Figs 15-16, 23)

Trachytes minima Trägårdh, 1910: 448; Hirschmann \& Zirngiebl-Nicol, 1965: 14; Pecina, 1970a: 423, 1970b: 56, 1980: 396; Błoszyk, 1980, 1999: 124; Mašán, 1999: 502, 2000 : 76.

Diagnosis. Female. Vertex short and without broad lateral margins. Dorsal shield strongly sculptured with large pentagonal and hexagonal pores; these pores with micropunctures marginally (similarly ventrally). Posterior marginal setae short, approximately 2/3 length of postmarginal setae. Holoventral shield present. Anterior part of sternal area with strongly sclerotized and curved band-like form posteriorly extending to anterolateral angles of genital shield. Sternal setae v1 absent or covered by sclerotized sculpturing. Setae v5 1.5 times longer than other sternal setae; line connecting adjacent bases of v2 and v3 setae oblique to longitudinal body axis. Genital 


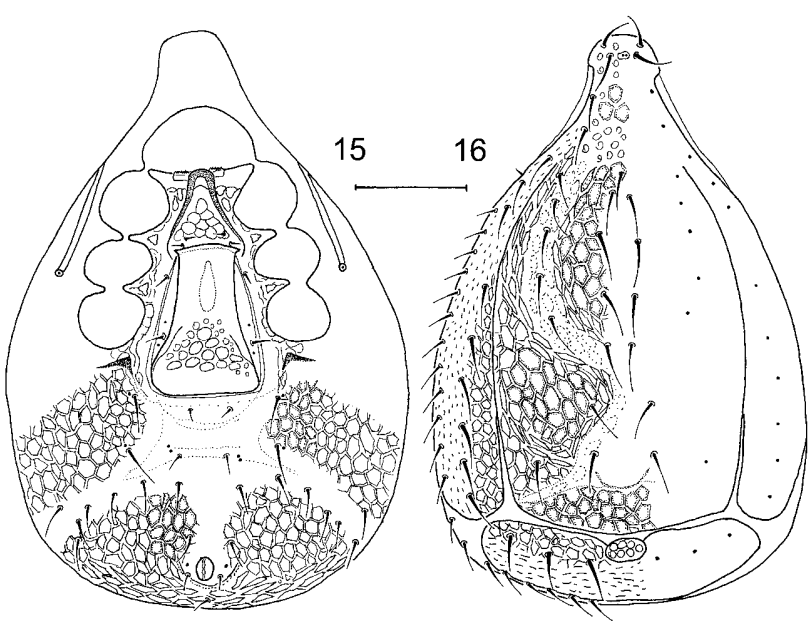

Figs 15-16. Trachytes minima ( $q) .15$ - ventral view; 16 dorsal view. Scale: $100 \mu \mathrm{m}$.

shield oblong, with regularly curved lateral margins and anterolateral points directed laterally, sculptured with large rounded circlets posteriorly. Ventrianal and inguinal areas with net-like sculpture, similarly to that on dorsum. Ventral setae $\mathrm{x} 1$ and $\mathrm{x} 3$ of aproximately equal size and $1 / 2-1 / 3$ length of setae $V 2$.

Distribution. North and Central Europe (Sweden, British Isles, Czech Republic, Poland, Slovakia and Ukraine).

Habitat. Edaphic detriticole. This species has a discontinuous distribution in Slovakia. It is particularly remarkable in showing a strong affinity for beech stands, which are widely distributed in Slovakia. It was found only in the border zones in East and West Slovakia (Fig. 32). It is most abundant in the litter of some virgin beech forests, and also abundant in beech stands admixed with deciduous trees like maple, elm, ash and birch or in birchlarch forests. For example, in Poland this species prefers beech-fire forests growing at altitudes between 400 and $900 \mathrm{~m}$ a. s. 1 (Błoszyk, 1999). In Slovakia it was found at altitudes ranging from 450 to $1,020 \mathrm{~m}$ a. s. 1., and most abundantly between 600 and $800 \mathrm{~m}$ a. s. 1 .

\section{Trachytes minimasimilis Mašán, 1999}

(Figs 17-18, 25)

Trachytes minimasimilis Mašán, 1999: 501, 2000: 77.

Diagnosis. Female. Vertex without broad lateral margins. Dorsal shield strongly sculptured with large pentagonal and hexagonal pores; these pores with micropunctures marginally (similarly ventrally). Posterior marginal setae short, approximately $1 / 4$ length of postmarginal setae. Holoventral shield present. Anterior margin of sternal area with strongly sclerotized ballshaped form. Sternal setae v1 absent or covered by sclerotized sculpturing, setae v2-v5 of equal size; line connecting bases of v2 and v3 setae oblique to longitudinal body axis. Genital shield oblong, with regularly curved lateral margins and anterolateral points directed laterally, medial sculpture of oval pores. Ventrianal and inguinal areas with net-like sculpture, similarly dorsally.

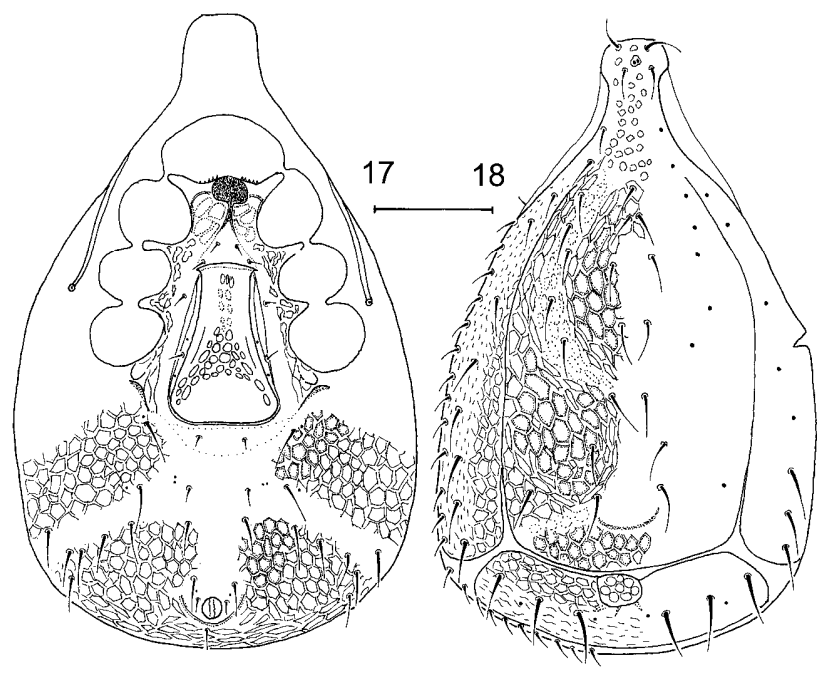

Figs 17-18. Trachytes minimasimilis (\%). 17 - ventral view; 18 - dorsal view. Scale: $100 \mu \mathrm{m}$.

Ventral setae $\mathrm{x} 1$ and $\mathrm{x} 3$ approximately $1 / 2-1 / 3$ length of setae V2.

Distribution. Slovakia. According to Huțu (verbal communication) also Poland and Romania (originally identified as $T$. minima)

Habitat. Edaphic detriticole. This species is presently known from Slovakia from localities in East Slovakia, from the border with Poland and Ukraine (Fig. 32). From the zoogeographical viewpoint it is probable that it is an East Carpathian element of the European fauna. Even in East Slovakia it is an uncommon stenotopic species that occurs infrequently. It was found in leaf litter in different types of broadleaved forests at altitudes between 350 and $600 \mathrm{~m}$ a. s. 1.

\section{Trachytes irenae Pecina, 1970}

(Figs 19-20, 29)

Trachytes irenae Pecina, 1970b: 45, 1980: 394; Błoszyk, 1980: 34, 1999: 118; Mašán, 2000: 78.

Diagnosis. Female. Vertex without broad lateral margins. Dorsal shield strongly sculptured laterally with flower-like pores. Posterior part of dorsal shield without distinct sculpture. Posterior marginal setae short, approximately 1/4-1/6 length of postmarginal setae. Holoventral shield present. Anterior margin of sternal area without strongly sclerotized forms and sculpture. Sternal setae v1-v 5 of equal size; line connecting bases of v2 and v3 setae approximately parallel to longitudinal body axis. Genital shield oblong, with regularly curved lateral margins and short anterolateral points directed laterally, finely sculptured with oval micropores posteriorly. Ventrianal area with flower-like pores marginally and without distinct sculpture medially. Ventral setae $\mathrm{x} 1$ and $\mathrm{x} 3$ of aproximately equal size and 1/3-1/4 length of setae V2.

Distribution. Central Europe (Czech Republic, Austria, Poland, Slovakia, Ukraine and Romania).

Habitat. Edaphic detriticole. A forest species of middle and high altitudes. In Slovakia it was found at altitudes 


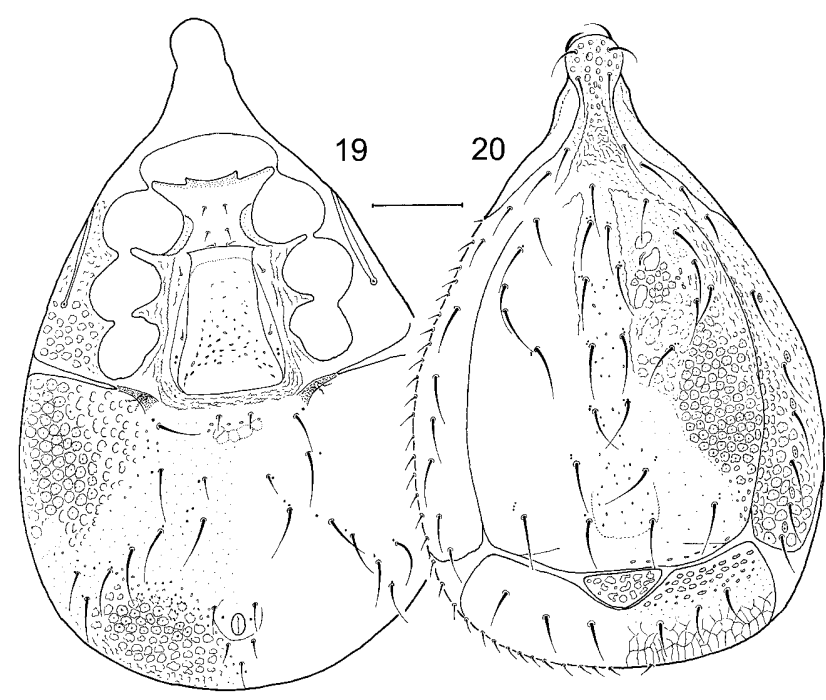

Figs 19-20. Trachytes irenae (\$). 19 - ventral view; 20 dorsal view. Scale: $100 \mu \mathrm{m}$.

from 380 to $1,840 \mathrm{~m}$ a. s. 1., and most abundantly between 700 and $1,200 \mathrm{~m}$ a. s. 1. It is missing in lowlands and areas with a Pannonian flora (Fig. 32). This species has a strong affinity for coniferous forests, which is atypical of representatives of Trachytes. It is most abundant in old spruce forests and less abundant in beech-fire forests and in homogenous beech forests. In some samples of litter from dwarf pine stands it was eudominant. In the oakbeech stands of middle altitudes it was rarely found and was uncommon in broadleaved forests in which beech was absent.

\section{Trachytes splendida Huțu, 1973}

(Figs 21-22, 30)

Trachytes splendida Huțu, 1973: 46; Mašán, 2000: 80.

Diagnosis. Female. Vertex without broad lateral margins. Dorsal shield strongly sculptured with irregularly rounded circlets. Posterior marginal setae short, approximately $1 / 3-1 / 4$ length of postmarginal setae. Holoventral shield present. Anterior margin of sternal area with 3 strongly sclerotized forms (plank-like, ring-like and bandlike sculptures) extending posteriorly to v2 and v3 setae. Sternal setae v1-v5 of equal size; line connecting bases of adjacent sternal setae v2 and v3 oblique to longitudinal body axis. Genital shield oblong, rectangular, with straight lateral margins and short anterolateral points directed anteriorly, sculptured with fine flower-like pores posteriorly and distinct irregular oval pores anteriorly. Adgenital platelets narrow (or covered by genital shield). Ventrianal and inguinal areas with flower-like sculpture. Ventral setae $\mathrm{x} 2$ and V2 of equal size and approximately 5-7 times longer than setae $\mathrm{x} 1$.

Distribution. Poland, Slovakia and Romania.

Habitat. Edaphic detriticole. Its distribution extends from the Romanian part of the Carpathians to northeastern Slovakia and southeastern Poland. Thus, from a zoogeographical viewpoint this species is an East Carpathian faunistic element. It occurs in forest habitats with a

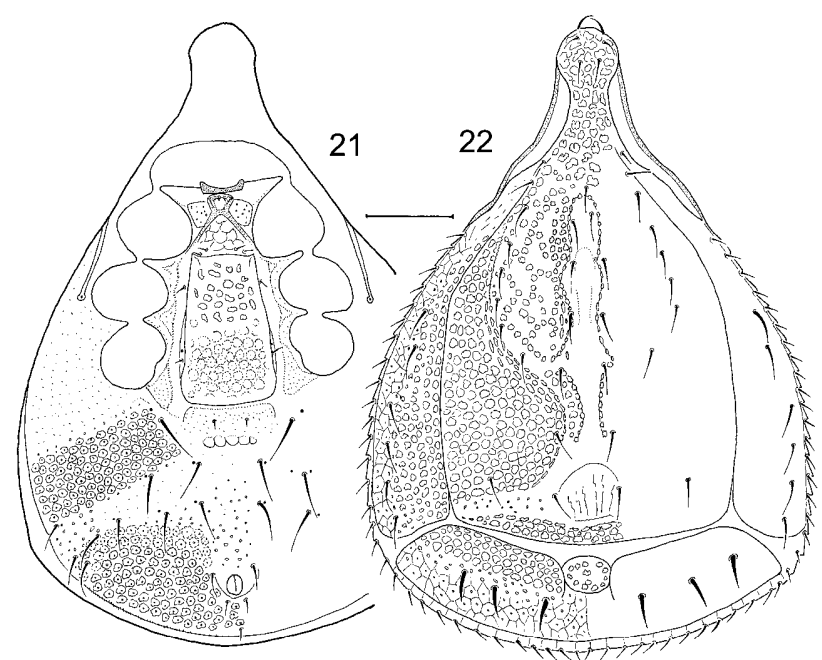

Figs 21-22. Trachytes splendida ( + ). 21 - ventral view; $22-$ dorsal view. Scale: $100 \mu \mathrm{m}$.

relatively high diversity of woody plants (virgin fire forests with beech, virgin beech forests, beech forest with elm, maple and oak, and lime-maple forests with elm and beech). In Slovakia it was found at altitudes ranging from 350 to $600 \mathrm{~m}$ a. s. 1 .

\section{ECOLOGICAL REQUIREMENTS AND ZOOGEOGRAPHY OF TRACHYTES SPECIES FROM SLOVAKIA}

Most of the Trachytes are edaphic detriticoles. They are hygrophilous and silvicolous species inhabiting litter, humus and fermentation soil layer and different kinds of soil detritus. There exist xerophilous species that are restricted to dry steppe-like and forest steppe-like habitats (T. baloghi). In such habitats, the soil-living species inhabit the grass rhizosphere.

Communities of Trachytes have a much higher species diversity and abundance in the broadleaved forests than in the coniferous forests. Only a few strongly psychrophilous species are abundant in acid soils of high altitude montane Norway spruce forests (Trachytes aegrota, T. hirschmanni, T. irenae, T. pauperior).

The composition and abundance of Trachytes mites in different habitats (vegetation stages) in Slovakia are presented in the Table 2. As a rule, species diversity in a habitat is low with mostly the euryecious and eurytopic species, $T$. aegrota a $T$. pauperior, strongly predominant. Other species are strongly predominant in particular habitats, T. baloghi in xerothermophilous habitats, and $T$. irenae and T. minima in beech forests.

Two parts of the Eurosiberian area meet in Slovakia: The provinces of broadleaved forests and steppes, which penetrate the southern parts of Slovakia to varying degrees. As indicated by the schematic map of the distribution of species in Slovakia (Fig. 32), the border between these provinces considerably limits the distribution of most silvicolous species, not only in Slovakia but probably also elsewhere. The zone where these provinces meet, namely the Pannonian and Subcarpathian section, is 


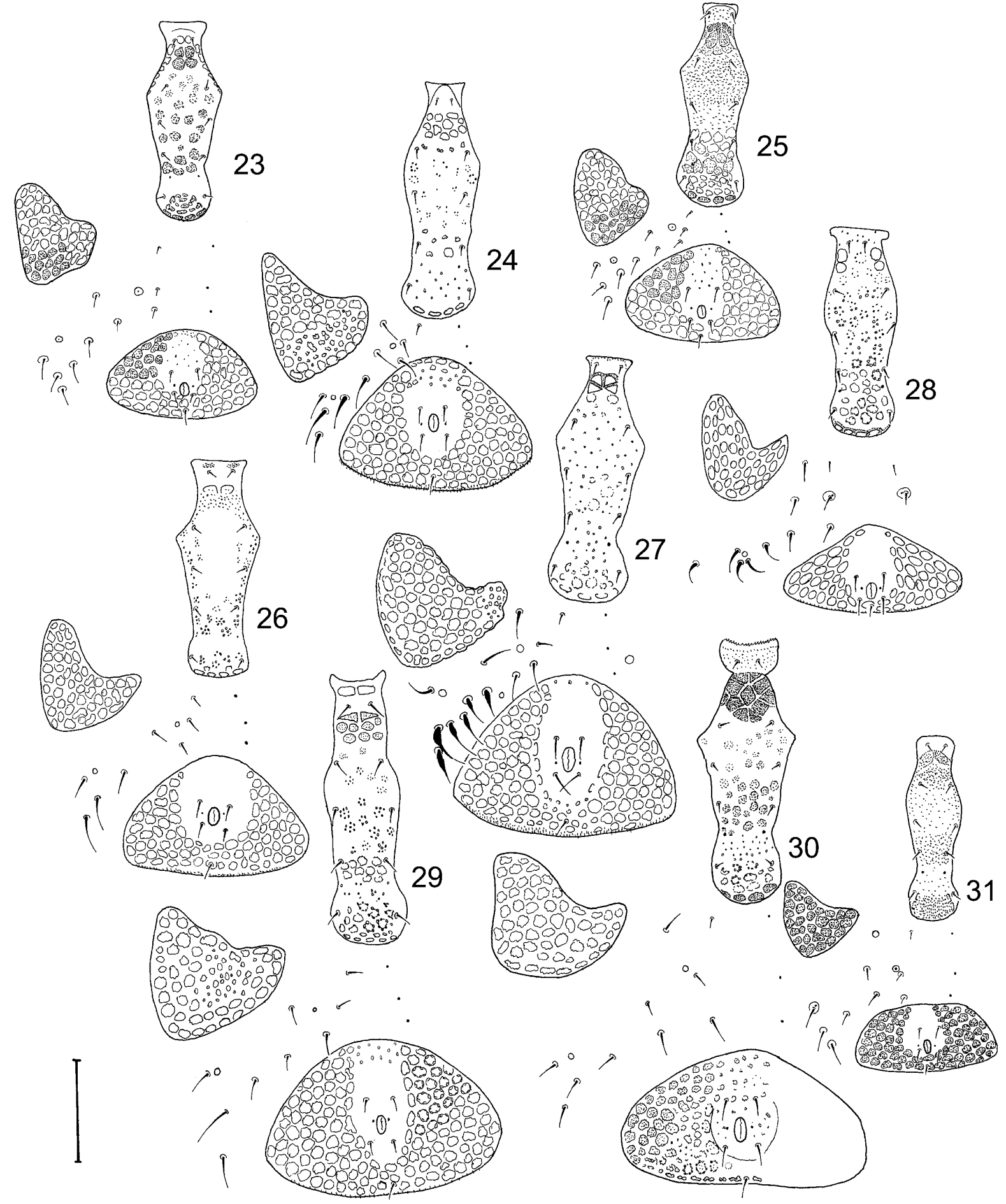

Figs 23-31. Ventral shields of deutonymphs. 23 - Trachytes minima; 24 - Trachytes baloghi; 25 - Trachytes minimasimilis; 26 Trachytes aegrota; 27 - Trachytes mystacinus; 28 - Trachytes lamda; 29 - Trachytes irenae; 30 - Trachytes splendida; 31 - Trachytes pauperior. Scale: $100 \mu \mathrm{m}$.

defined by phytocoenologists as the border of distribution of the Pannonian flora (Fig. 32).

Because of the limited mobility of mites, they are drastically affected by the Quarternary glaciations and climatic changes. Probably mites were more affected than the more mobile insects. This is indicated by the proportion of Mediterranean species among the edaphic species, which is considerably lower than for phoretic species inhabiting other types of microhabitats. As is well known, the edaphic detriticoles are not phoretic. Therefore, their ability to colonise suitable habitats is considerably limited. Among the Trachytes species occurring in Slovakia, only the distribution area of $T$. baloghi overlaps that of the Pannonian flora in South Slovakia (Fig. 32). For this reason it is highly probable that species showing a 


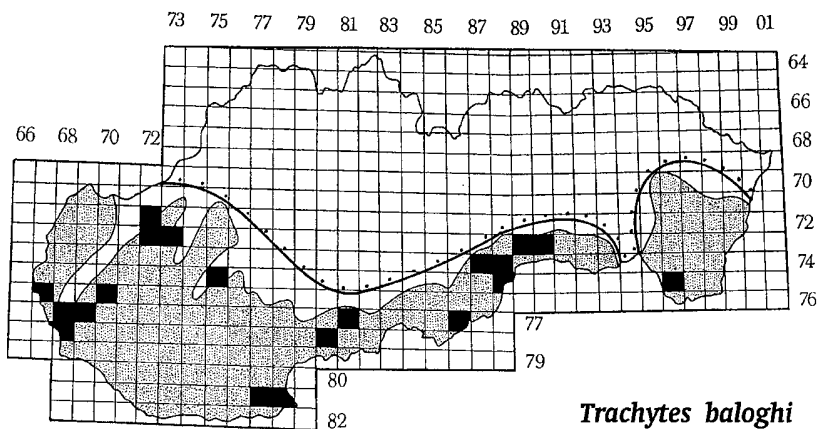

$\begin{array}{lllllllllllllll}73 & 75 & 77 & 79 & 81 & 83 & 85 & 87 & 89 & 91 & 93 & 95 & 97 & 99 & 01\end{array}$

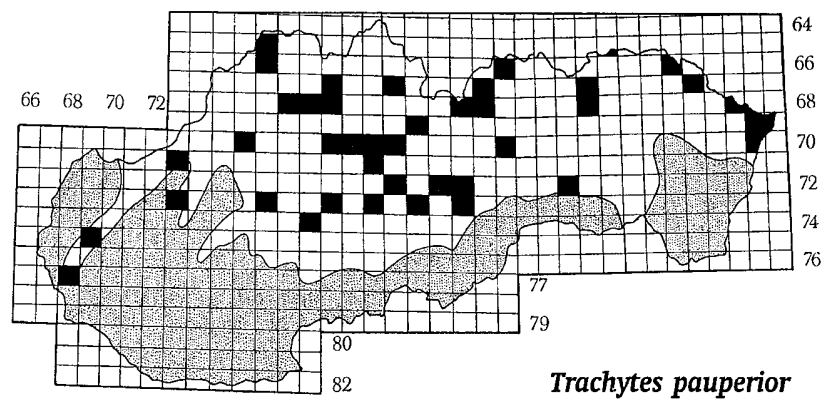

$\begin{array}{lllllllllllllll}73 & 75 & 77 & 79 & 81 & 83 & 85 & 87 & 89 & 91 & 93 & 95 & 97 & 99 & 01\end{array}$

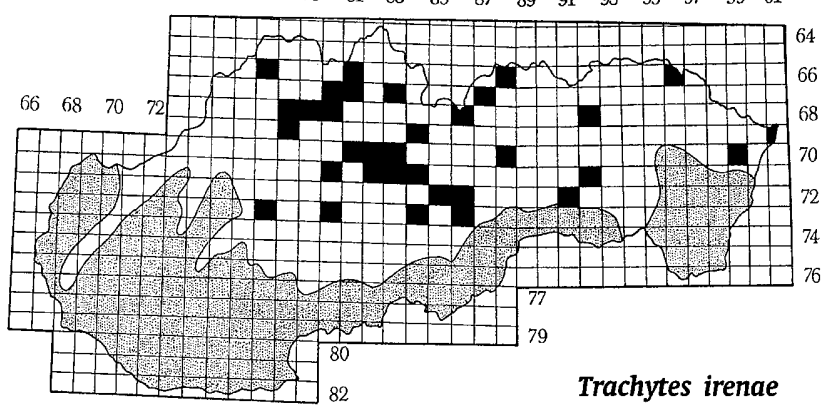

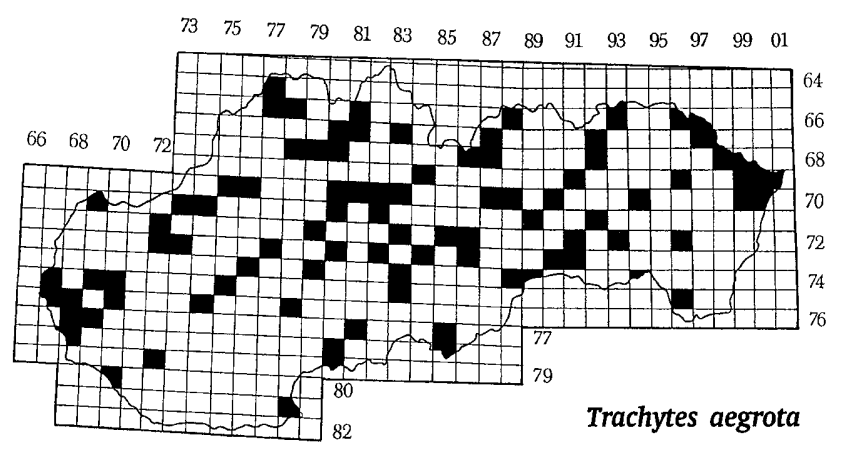

$\begin{array}{lllllllllllllll}73 & 75 & 77 & 79 & 81 & 83 & 85 & 87 & 89 & 91 & 93 & 95 & 97 & 99 & 01\end{array}$

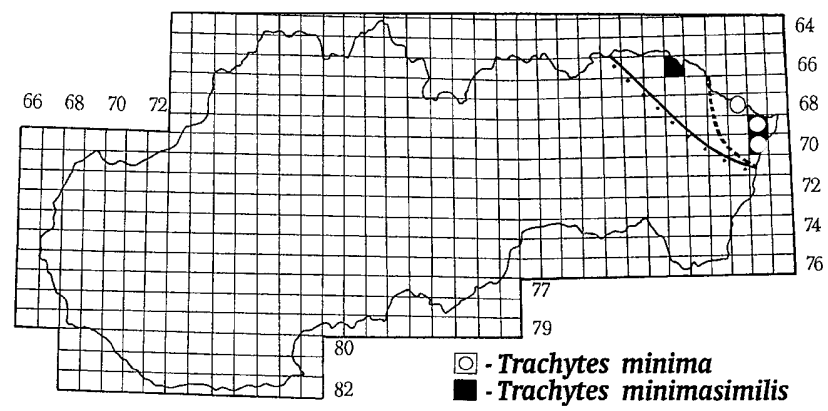

$\begin{array}{lllllllllllllll}73 & 75 & 77 & 79 & 81 & 83 & 85 & 87 & 89 & 91 & 93 & 95 & 97 & 99 & 01\end{array}$

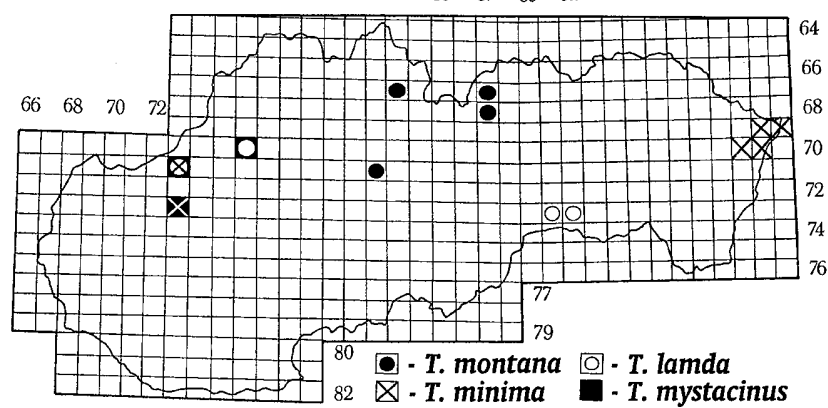

Fig. 32. Distribution of Trachytes species in Slovakia with the predicted border of the ranges (._._.. , _ . - ) for some species (dotted area represents Pannonian flora distribution).

similar type of distribution originate from Mediterranean refuges.

Another obvious biogeographical divide in Slovakia is the border between the West- and East Carpathian sections of the subprovince of Carpathian mountain ranges, i.e. parts of the province of Central European Mountain ranges. The East Carpathian section includes the easternmost part of Slovakia. In Poland, it includes a similarly large southeastern part of the country (Błoszyk, 1998). As in Poland, the East Carpathian endemic elements T. splendida and T. minimasimilis are also present in the Slovak fauna.

TABLE 3. Vertical distribution of Trachytes species in Slovakia.

\begin{tabular}{|c|c|c|c|c|c|c|c|c|c|}
\hline \multirow[t]{2}{*}{ Species } & \multicolumn{9}{|c|}{ Altitude [m a. s. 1.] } \\
\hline & $0-250$ & $250-500$ & $500-750$ & $750-1,000$ & $1,000-1,250$ & $1,250-1,500$ & $1,500-1,750$ & $1,750-2,000$ & $2,000-2,250$ \\
\hline Trachytes aegrota & $\cdots--$ & ---++ & +++++ & +++++ & ++--- & ----- & ----- & ----- & $---\cdots$ \\
\hline Trachytes baloghi & $\cdots-+$ & $++-\cdots$ & $\cdots \cdots$ & $\cdots \cdots$ & $\cdots \cdots$ & $\cdots \cdots$ & $\cdots \cdots$ & $\cdots \cdots$ & $\cdots \cdots$ \\
\hline Trachytes hirschmanni & $\cdots \cdots$ & $\cdots \cdots$ & $\cdots \cdots$ & $\cdots \cdots$ & $\cdots \cdots$ & $\cdots--$ & ----- & ----- & - \\
\hline Trachytes irenae & $\cdots \cdots$ & $\cdots--$ & ----+ & +++++ & ++++- & ----- & ----- & $--\cdots$ & $\cdot$ \\
\hline Trachytes lamda & $\cdots \cdots$ & $\cdots \cdot-$ & ----- & $----\cdot$ & $\cdots \cdots$ & $\cdots \cdots$ & $\cdots \cdots$ & $\cdots \cdots$ & $\cdots \cdots$ \\
\hline Trachytes minima & $\cdots$ & $\cdots \cdot-$ & --+++ & +---- & $\cdots \cdots$ & $\cdots$ & $\cdots \cdots$ & $\cdots \cdots$ & $\cdots \cdots$ \\
\hline Trachytes minimasimilis & $\cdots \cdots$ & $\cdots---$ & $--\cdots$ & $\cdots \cdots$ & $\cdots \cdots$ & $\cdots \cdots$ & $\cdots \cdots$ & $\cdots \cdots$ & $\cdots \cdots$ \\
\hline Trachytes mystacinus & $\cdots \cdots$ & $\cdot-++$ & ++--- & $----\cdot$ & $\cdots \cdots$ & $\cdots \cdots$ & $\cdots \cdots$ & - & $\cdots$ \\
\hline Trachytes pauperior & $\cdots \cdot-$ & ----- & --+++ & +++++ & +++++ & +++++ & +++++ & +---- & $---\cdots$ \\
\hline Trachytes splendida & $\cdots \cdots$ & $\cdot \cdot---$ & $--\cdots$ & $\cdots \cdots$ & $\cdots \cdots$ & $\cdots \cdots$ & $\cdots \cdots$ & $\cdots \cdots$ & $\cdots \cdots$ \\
\hline
\end{tabular}

Explanations: -- present, +++- most frequent and abundant, $\cdots-$ not found $(-,+$ or $\cdot=$ vertical range of 50 meters). 
Finding these species in Slovakia extended their known distribution range. Also the border of distribution of $T$. mystacinus runs through Slovakia (western territory), similar to that of East Carpathian and Mediterranean species (Fig. 32).

In terms of vertical distribution (Table 3 ) the Trachytes species occuring in Slovakia can be classified into 4 groups:

1. Euryzonal species range from lowlands (T. aegrota) or foothills ( $T$. pauperior) to the zone of dwarf pines and are distributed over most of the Palaearctic. There are holarctic species, T. aegrota, which are also recorded in North America. T. pauperior is distributed throughout the Eurosiberian area.

2. Thermophilous species live in the lowlands or xerophilous phytocoenoses in the foothills (T. baloghi) and are distributed in Southern Europe (species of Mediterranean origin).

3. Species living in broadleaved forests at middle altitudes, in the highland and submontane zone. They are distributed throughout Europe ( $T$. lamda and $T$. minima) or found only in a part of Europe (T. minimasimilis and $T$. splendida are East Carpathian endemic elements).

4. Montane species distributed mostly in the zone of coniferous forests and reaching that of dwarf pine. They are distributed in Central Europe, as a Carpathian endemic elements are restricted to the Carpathian mountain ranges ( $T$. hirschmanni and $T$. irenae).

\section{REFERENCES}

Athias-Binche F. 1980: Contribution à la connaissance des Uropodides libres (Arachmides: Anactinotriches) de quelques écosystčmes forestiers européens. Première partie - Morphologie, systématique et biologie. Thèse Doct. Univ. P. et M. Curie. Paris, 80 pp.

Berlese A. 1887: Acari, Myriapoda et Scorpiones Hucusque in Italia Reperta. Ordo Mesostigmata (Gamasides). Portici et Padua, $143 \mathrm{pp}$.

BerLese A. 1903: Acari nuovi. Manipulus II. Redia 1: 258-280.

Berlese A. 1910: Brevi diagnosi di generi e specie nuovidi Acari. Redia 6: 346-388.

Berlese A. 1914: Acari nuovi. Manipulus IX. Redia 10 $113-150$.

BloszyK J. 1980: Mites of the genus Trachytes Michael, 1894 (Acari, Mesostigmata) in Poland. Pr. Kom. Biol. PTPN 54 5-52. [in Polish, English abstr.]

BłoszYK J. 1984: Altitudinal distribution of the Uropodina fauna (Acari) in Poland. Przegl. Zool. 28: 69-71. [in Polish, English abstr.]

BloszyK J. 1998: East Carpathian geographical elements in the mite fauna of Poland. Biol. Bull. Poznań 35: 137-147.

BłoszyK J. 1999: Geograficzne i Ekologiczne Zróżnicowanie Zgrupovań Roztoczy z Kohorty Uropodina (Acari: Mesostigmata) w Polsce. I. Uropodina Lasów Gradowych (Carpinion betuli). Wydawnictwo Kontekst, Poznan, 245 pp.

BłoszyK J. \& Olszanowski Z. 1985: Mites of the genus Trachytes Michael, 1894 (Acari, Mesostigmata) in Poland. III. Sporadic appearance of males in some populations of parthenogenetic species. Przegl. Zool. 29: 313-316. [in Polish, English abstract]
HiRschmann W. 1993: Gangsystematik der Parasitiformes. Teil 550. Bestimmungstabellen der Uropodiden der Erde, Atlas der Ganggattungen der Atrichopygidiina. Acarologie, Schriftenreihe für Vergleichende Milbenkunde. Folge 40, Hirschmann-Verlag, pp. 292-370.

Hirschmann W. \& ZrrngieBl-Nicol I. 1961: Gangsystematik der Parasitiformes. Teil 4. Die Gattung Trichouropoda Berlese 1916 nov. comb., die Cheliceren und das System der Uropodiden. Acarologie, Schriftenreihe für Vergleichende Mitbenkunde. Folge 4, Hirschmann-Verlag, pp. 1-41.

Hirschmann W. \& Zrrngiebl-Nicol I. 1964: Gangsystematik der Parasitiformes. Teil 7. Uropodiden. Das Gangsystem der familie Uropodidae (Berlese, 1892) Hirschmann und Zirngiebl-Nicol nov. comb. Bestimmungstabellen, Kurzdiagnosen, Operculum-Bestimmungstabellen. Acarologie, Schriftenreihe für Vergleichende Milbenkunde. Folge 6, Hirschmann-Verlag, pp. 1-22.

HirschmanN W. \& Zrrngiebl-Nicol I. 1965: Gangsystematik der Parasitiformes. Teil 9. Uropodiden. Bestimmungstabellen von 300 Uropodiden-Arten (Larven, Protonymphen, Deutonymphen, Weibchen, Männchen). Acarologie, Schriftenreihe für Vergleichende Milbenkunde. Folge 8, Hirschmann-Verlag, pp. $1-33$.

Hirschmann W. \& Zirngiebl-Nicol I. 1969: Gangsystematik der Parasitiformes. Teil 42. Sechs neue Trachytes-Arten. Acarologie, Schriftenreihe für Vergleichende Milbenkunde. Folge 12, Hirschmann-Verlag, pp. 36-39.

Huțu M. 1973: Gangsystematik der Parasitiformes. Teil 145. Zur Kenntnis der Uropodiden-Fauna Rumäniens. Neue Uropodiden-Arten der Gattungen Trachytes Michael, 1894, Dinychus Kramer, 1886 und Trachyuropoda (Berlese, 1888) Hirschmann u. Zirngiebl-Nicol, 1961 nov. comb. Acarologie, Schriftenreihe für Vergleichende Milbenkunde. Folge 19, Hirschmann-Verlag, pp. 45-51.

Huțu M. 1982: Strukturelle eigenschaften von UropodidenZönosen in der Streuschicht verschiedeer Waldtypen längs eines Höhengradients. Pedobiologia 23: 68-89.

HuȚU M. 1983: Gangsystematik der Parasitiformes. Teil 428. Teilgänge, Stadien von 6 neuen Trachytes-Arten aus Rumänien und Sweden (Uropodini, Uropodinae). Acarologie, Schriftenreihe für Vergleichende Milbenkunde. Folge 30, Hirschmann-Verlag, pp. 51-66.

Kadite B.A. \& Petrova A.D. 1977: Kogorta Trachytina, sem. Trachytidae. In: Bregetova N.G., Vaishtein B.A., Kadite B.A., Koroleva E.V., Petrova A.D., Tikhomirov S.I. \& Shcherbak G I. (eds): Opredelitel Obitaiushchikh v Pochve Kleshchei, Mesostigmata. Izdatelstvo Nauka, Leningrad, pp. 621-632.

KARG W. 1989: Acari (Acarina), Milben. Unterordnung Parasitiformes (Anactinochaeta), Uropodina Kramer, Schildkrötenmilben. Die Tierwelt Deutschlands. 67. Teil, VEB Gustav Fischer Verlag Jena, $203 \mathrm{pp}$.

Kocн C.L. 1841: Deutschlands Crustaceen, Myriapoden und Arachniden. Heft 32. F. Pustet, Regensburg, 222 pp.

KRAMER P. 1876: Zur Naturgeschichte einiger Gattungen aus der Familie der Gamasiden. Arch. Naturgesch. 42: 46-105.

MAŠÁN P. 1999: New species of the genera Trachytes, Trichouropoda, Nenteria and Oplitis (Acarina, Mesostigmata, Uropodina) from Slovakia. Biologia, Bratislava 54: 501-514.

MAŠÁN P. 2000: Mites of the Cohort Uropodina (Acarina: Mesostigmata) in Slovakia. Ph.D. thesis, Institute of Zoology, Slovak Academy of Sciences, Bratislava, 282 pp. [in Slovak]

Michael A.D. 1894: Notes on the Uropodina. J. Royal Microscop. Soc. 1894: 289-319.

Pecina P. 1970a: Contribution to the knowledge of Uropodidae (Berlese, 1892) sensu Hirschmann et Zirngiebl-Nicol, 1964, 
of the environs of Prague (Acari, Mesostigmata). Acta Univ. Carol. (Biol.) 1968: 417-434.

Pecina P. 1970b: Czechoslovak uropodid mites of the genus Trachytes Michael, 1894 (Acari, Mesostigmata). Acta Univ. Carol. (Biol.) 1969: 39-59.

Pecina P. 1980: Additional knowledge of members of the genus Trachytes Michael, 1894 (Acari, Mesostigmata) from Czechoslovakia. Acta Univ. Carol. (Biol.) 1978: 389-407.
SChweIzer J. 1961: Die Landmilben der Schweiz (Mittelland, Jura und Alpen). 1. Teil: Parasitiformes Reuter. Dkschr. Schweiz Natf. Ges. Zürich 84: 1-207.

TräGARDH I. 1910: Acariden aus dem Sarekgebirge. Nat. Wiss. Unters. Sarekgeb. 4: 375-586.

ZIRNGIEBL-NiCOL I. 1973: Gangsystematik der Parasitiformes. Teil 135. Wiederbeschreibung von 7 bekannten TrachytesArten. Acarologie, Schriftenreihe für Vergleichende Milbenkunde. Folge 19, Hirschmann-Verlag, pp. 10-14.

Received March 4, 2002; revised November 6, 2002; accepted December 9, 2002 